\title{
IMPLEMENTASI MODEL PEMBELAJARAN CREATIVE PROBLEM SOLVING UNTUK SISWA KELAS AWAL SEKOLAH MENENGAH KEJURUAN
}

\author{
Adang Effendi ${ }^{1}$, Ai Tusi Fatimah ${ }^{2}$ \\ 1,2 Universitas Galuh, Jl. R. E. Martadinata No.150, Ciamis, Indonesia \\ email: adangeffendi72@gmail.com
}

\begin{abstract}
This study aimed to obtain an overview of the implementation of creative problem solving (CPS) learning models in early grades vocational high school or SMK. This study uses a case study method to describe the implementation of the CPS learning model for students of SMK of Banking Syariah X class in Ciamis, Indonesia. The early grade is students who are new learning mathematical topics in $X$ class. The data in this study came from observations, interviews, and documentation. Data analysis of syntax, social systems, teacher roles, support systems, instructional and accompaniment impacts. The results of this study indicate that: (1) identification of early grade problems and the goals of vocational education is needed to plan the implementation of CPS learning models in SMK, (2) the syntax of CPS learning models can be implemented in stages in early grade students with gradual social arrangements and supported by appropriate support system so that the teacher can play the right role and give instructional and accompaniment impact as planned. The researcher can implement the CPS model in the spectrum of other vocational skills.
\end{abstract}

Keywords: creative problem solving, early grade, vocational high school

\begin{abstract}
ABSTRAK
Tujuan penelitian ini adalah untuk memperoleh gambaran tentang implementasi model pembelajaran creative problem solving (CPS) pada siswa kelas awal sekolah menengah kejuruan (SMK). Penelitian ini menggunakan metode studi kasus untuk mendeskripsikan implementasi model pembelajaran CPS pada siswa SMK Perbankan Syariah kelas X di Ciamis, Indonesia. Siswa kelas awal merupakan siswa kelas $X$ yang baru mengikuti pembelajaran pada topik matematika. Data pada penelitian ini berasal dari observasi, wawancara, dan dokumentasi. Analisis data terhadap aspek sintaks, sistem sosial, peran guru, sistem pendukung, dampak-dampak instruksional dan pengiring. Hasil penelitian ini menunjukkan bahwa: (1) diperlukan identifikasi masalah kelas awal dan tujuan pendidikan SMK untuk merencanakan implementasi model pembelajaran CPS di SMK, (2) sintaks model pembelajaran CPS dapat diimplementasikan secara bertahap pada siswa kelas awal dengan pengaturan sosial yang bertahap dan didukung dengan sistem pendukung yang tepat sehingga guru dapat berperan secara tepat dan memberi dampak instruksional dan pengiring seperti yang sudah direncanakan. Peneliti selanjutnya dapat mengimplementasikan model CPS pada spektrum keahlian SMK yang lainnya.
\end{abstract}

Kata Kunci: creative problem solving, kelas awal, sekolah menengah kejuruan

Dikirim : 13 Agustus 2019; Diterima: 27 September 2019; Dipublikasikan : 30 September 2019

Cara sitasi: Effendi, A., \& Fatimah, A. T. (2019). Implementasi model pembelajaran creative problem solving untuk siswa kelas awal sekolah menengah kejuruan. Teorema: Teori dan Riset Matematika, 4(2), 89-98. 


\section{PENDAHULUAN}

Model Creative Problem Solving (CPS) telah diimplementasikan pada beberapa penelitian. Hasilnya menunjukkan bahwa CPS berhasil meningkatkan kemampuan siswa baik dari segi kognitif maupun afektif. Kemampuan komunikasi matematis siswa SMP yang memperoleh model CPS lebih baik dibandingkan dengan siswa yang memperoleh pembelajaran langsung (Apiati \& Fatimah, 2017). Melalui model pembelajaran CPS, rata-rata kemampuan pemecahan masalah mahasiswa pada setiap siklus pembelajaran meningkat (Turmuzi, et. al., 2018). CPS mampu meningkatkan Self Regulated Learning siswa SMA secara signifikan lebih baik jika dibandingkan dengan siswa yang memperoleh pembelajaran konvensional (Effendi, 2016a). Terdapat perbedaan peningkatan kemampuan metakognitif yang signifikan antara siswa SMA yang memperoleh model pembelajaran CPS dengan siswa yang memperoleh pembelajaran konvensional (Effendi, 2016b, 2017). Berdasarkan penelitian-penelitian tersebut tebukti bahwa model pembelajaran CPS ampuh meningkatkan berbagai kemampuan siswa pada berbagai jenjang pendidikan.

Pepkin (2004) menyatakan empat tahapan pembelajaran CPS yaitu klarifikasi masalah, pengungkapan pendapat, evaluasi dan pemilihan, dan implementasi. Klarifikasi masalah adalah tahap memberikan penjelasan kepada siswa tentang masalah yang diajukan. Tujuannya agar siswa dapat memahami tentang penyelesaian seperti apa yang diharapkan. Pengungkapan pendapat adalah memberikan kebebasan kepada siswa untuk mengungkapkan pendapat tentang berbagai macam strategi penyelesaian masalah. Evaluasi dan pemilihan adalah tahap diskusi kelompok. Siswa mendiskusikan pendapat-pendapat atau strategi-strategi yang cocok untuk menyelesaikan masalah. Implementasi adalah menentukan strategi mana yang dapat diambil untuk menyelesaikan masalah, kemudian menerapkannya sampai menemukan penyelesaian dari masalah tersebut.

Model pembelajaran CPS dirancang dan diimplementasikan seperti model pembelajaran lain pada umumnya. Joyce, et. al (2009) menyatakan bahwa model pembelajaran memiliki karakteristik umum yaitu memiliki sintaks, sistem sosial, peran guru, sistem pendukung, dampak-dampak instruksional dan pengiring. Sintaks merupakan tahap-tahap kegiatan yang dilakukan dalam pembelajaran menurut model tertentu. Sistem sosial meliputi suasana dan norma yang berlaku dalam model tersebut. Peran guru merupakan kegiatan yang menggambarkan bagaimana guru memperlakukan dan memberi respon kepada siswa. Sistem pendukung meliputi segala sarana, bahan, dan alat yang diperlukan untuk melaksanakan suatu model pembelajaran tertentu. Dampak instruksional yaitu hasil belajar yang dicapai langsung dengan cara mengarahkan para siswa pada tujuan yang ditetapkan. Dampak pengiring yaitu hasil belajar lainnya yang dihasilkan oleh suatu proses pembelajaran.

Model pembelajaran CPS dalam penelitian ini diimplementasikan melalui studi kasus terhadap siswa sekolah menengah kejuruan (SMK). Banyak hal yang harus dipertimbangkan dalam mengimplementasikan suatu model pembelajaran di SMK, karena tujuan pendidikan di SMK memiliki karakteristik khusus. Berdasarkan Undang-Undang Nomor 20 Tahun 2003 pendidikan SMK bertujuan untuk mempersiapkan siswa terutama bekerja sesuai dengan keahliannya. Konsekuensi dari tujuan pendidikan tersebut menunutut semua pihak untuk mendukungnya, tak terkecuali guru matematika dalam melakukan pembelajaran di kelas.

Permendikbud Nomor 34 Tahun 2018 menyatakan bahwa standar kompetensi lulusan Mata Pelajaran Matematika adalah siswa memiliki pemahaman matematika dalam melaksanakan tugas sesuai keahliannya yang terdeskripsi dalam empat standar isi. Di sisi lain, SMK memiliki spektrum keahlian yang beragam yang memberi konsekuensi keragaman pemahaman matematis yang harus disesuaikan dengan bidang/program/kompetensi keahlian. Konsekuensi tersebut harus dilakukan dalam proses belajar mengajar matematika mulai dari perencanaan, pelaksanaan, dan evaluasi. Fatimah \& Amam (2018) menyatakan bahwa diperlukan pengembangan RPP matematika SMK yang disesuaikan dengan kebutuhan siswa dan pengetahuan matematika kejuruan di dunia kerja sesuai bidang keahlian siswa. 
Identifikasi matematika yang dibutuhkan dalam memecahkan masalah kejuruan merupakan salah satu titik tolak dalam mempersiapkan pembelajaran matematika. Belum banyak peneliti yang berusaha mengidentifikasi kebutuhan matematika pada suatu kompetensi keahlian. Misalnya Fatimah \& Zakiah (2019) berusaha mengidentifikasi matematika pada SMK Teknik dan Bisnis Sepeda Motor. Padahal, dengan mengetahui kebutuhan matematika pada suatu kompetensi keahlian, dapat memanfaatkannya dalam membuat konteks (masalah) untuk bahan ajar dan tugas (soal-soal) latihan maupun ujian. Melalui konteks yang disajikan pada tugas matematis di kelas, siswa dapat memiliki pengalaman belajar sesuai bidang keahliannya. Fatimah, et. al (2019) menyatakan bahwa tugas dengan konteks agribisnis membantu penalaran siswa dalam memecahkan tugas matematis. Fatimah \& Zakiah (2018) menganalisis kelancaran prosedural matematis siswa dalam memecahkan masalah dalam konteks pemasaran yang menunjukkan bahwa konteks yang disajikan dapat menuntun siswa sukses mencapai penyelesaian yang masuk akal. Fatimah, et. al. (2018) mengoneksikan fungsi permintaan dan penawaran dengan persamaan linear dua variabel atau fungsi linear serta memanfaatkan masalah permintaan dan penawaran untuk memperkenalkan konsep peluang dan sistem persamaan linear dua variabel.

Beragam konteks keahlian kejuruan tentunya dapat dimanfaatkan untuk menghadirkan beragam bahan ajar matematika di kelas. Melalui model pembelajaran CPS sangat memungkinkan konteks tersebut dihadirkan di kelas, tak terkecuali di kelas awal. Hal tersebut diduga merupakan salah satu upaya untuk menarik minat siswa belajar matematika di awal-awal pembelajaran matematika. Berdasarkan pemaparan tersebut, tulisan ini akan menggambarkan implementasi model pembelajaran CPS di SMK Keahlian Perbankan Syariah Kelas X dengan topik/materi Operasi Bilangan Real.

\section{METODE PENELITIAN}

Metode penelitian ini adalah studi kasus untuk memperoleh gambaran implementasi model pembelajaran CPS. Penelitian ini melibatkan satu orang guru dan 30 siswa kelas X SMK Keahlian Perbankan Syariah. Peneliti terlibat dalam perencanaan dan berperan sebagai observer pada saat CPS diimplementasikan di kelas. Dokumentasi dilakukan melalui video dan rekaman suara. Tahapan proses penelitian ini merujuk pada Hancock \& Algozzine (2006) sebagai berikut:

1) Peletakkan awal untuk menentukan fenomena yang akan diteliti, yaitu implementasi model pembelajaran CPS di kelas awal SMK Keahlian Perbankan Syariah Kelas X pada topik operasi bilangan real (bentuk pangkat, akar, dan logaritma).

2) Menentukan apa yang diketahui, yaitu berdasarkan wawancara dengan guru SMK dan dokumen yang berkaitan dengan Model CPS maupun peraturan/perundangan SMK. Pada bagian ini dilakukan pengidentifikasian masalah siswa kelas awal dan sumber daya yang mendukung implementasi CPS.

3) Memilih desain studi kasus yaitu desain deskriptif untuk menggambarkan implementasi model CPS mulai dari perencanaan hingga pelaksanaannya.

4) Mengumpulkan informasi melalui observasi dan dokumentasi. Observasi dan dokumentasi dilakukan untuk melihat implementasi CPS dari aspek sintaks, sistem sosial, peran guru, sistem pendukung, dampak-dampak instruksional dan pengiring.

5) Merangkum dan menginterpretasi informasi yang diperoleh dari observasi dan dokumentasi.

6) Melaporkan temuan selama proses implementasi model CPS.

7) Mengonfirmasi temuan studi kasus dengan membandingkannya dengan teori atau hasil penelitian yang telah dilakukan sebelumnya. 


\section{HASIL DAN PEMBAHASAN}

Hasil penelitian ini menggambarkan tahap perencanaan dan pelaksanaan dari proses implementasi model pembelajaran CPS. Tahap perencanaan merupakan tahap mengidentifikasi masalah siswa di kelas awal dan dokumen tentang SMK. Hasil identifikasi masalah ditunjukkan dalam skema pada Gambar 1 berikut ini.

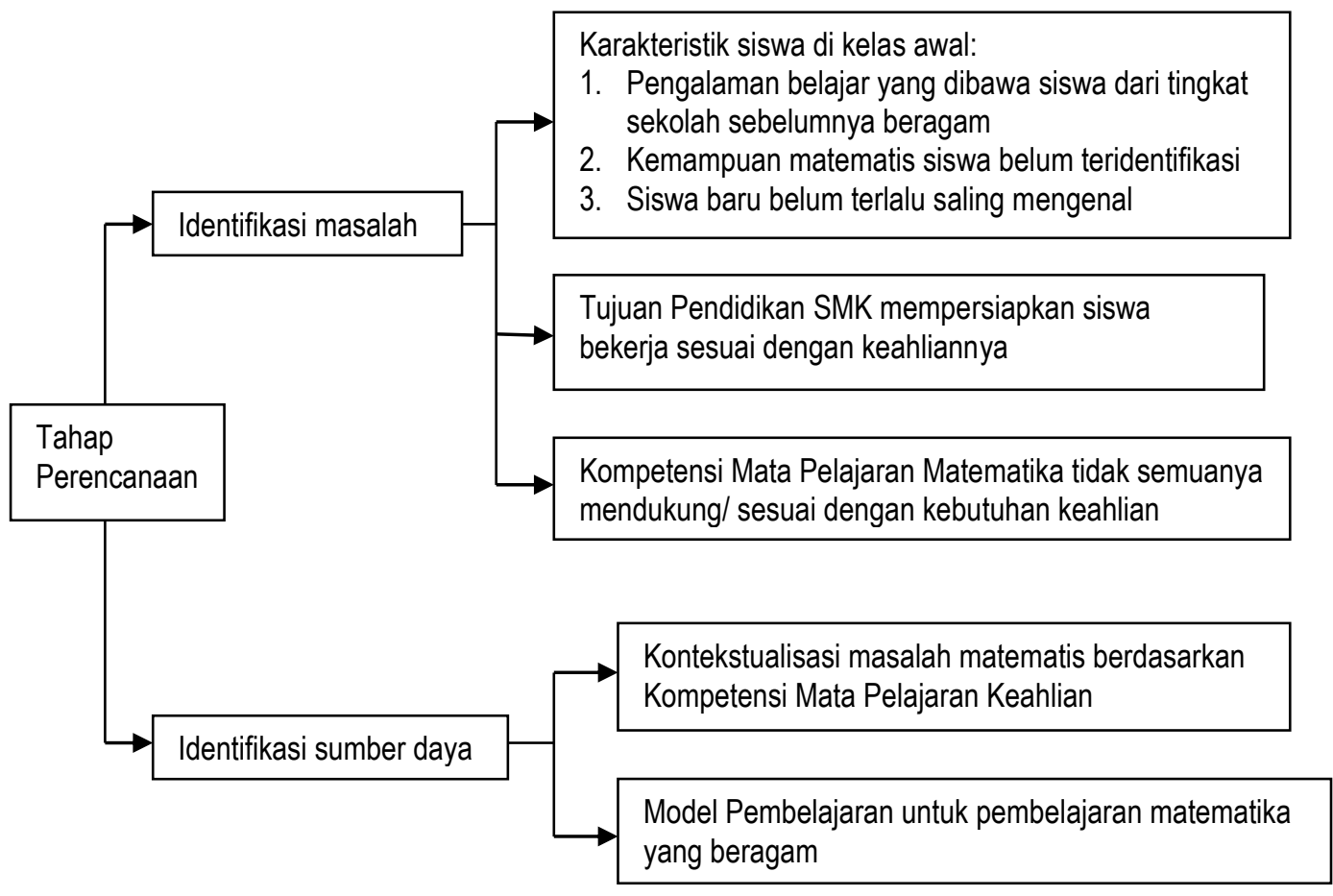

Gambar 1. Skema hasil identifikasi masalah dan sumber daya

Hasil identifikasi terhadap masalah dan sumber daya pada Gambar 1 digunakan untuk merencanakan penggunaan sintaks, sistem sosial, peran guru, sistem pendukung, dampak-dampak instruksional dan pengiring. Sintak yang digunakan dalam penelitian ini merujuk pada model CPS Pepkin (2004). Implementasi model pembelajaran CPS pada penelitian ini dilakukan selama enam kali pertemuan. Dua pertemuan pertama, siswa dikelompokkan secara berpasangan sesuai tempat duduk masing-masing (siswa duduk satu bangku dua orang). Hal tersebut dilakukan untuk mempermudah identifikasi kemampuan awal matematis dan pengalaman belajar yang telah diperoleh oleh masing-masing siswa. Dalam hal ini siswa diduga sudah mengenal dengan baik teman sebangkunya sehingga interaksi antara dua orang siswa akan berjalan dengan baik dan lancar. Pada pertemuan ketiga dan keempat, siswa dibagi menjadi enam kelompok yang masingmasing kelompok terdiri dari lima orang siswa. Anggota kelompok ditentukan oleh peneliti dan guru dengan mempertimbangkan posisi tempat duduk siswa yang berdekatan. Pada dua pertemuan terakhir, siswa dikelompokkan secara heterogen dengan berpindah tempat duduk (baris maupun lajur). Hal tersebut dilakukan supaya siswa memiliki interaksi sosial yang lebih beragam. Siswa yang teridentifikasi memiliki kemampuan matematis tinggi dapat memberi bantuan terhadap teman satu kelompoknya.

Peneliti dan guru membuat denah tempat duduk siswa untuk mempermudah observasi dan menentukan pengelompokkan pada pertemuan selanjutnya. Peran guru dalam penelitian ini direncanakan sebagai fasilitator pembelajaran dan memberi scaffolding jika diperlukan oleh siswa. Pembelajaran dilakukan dengan fasilitas LKS. Tabel 1 berikut merangkum perencanaan implementasi model pembelajaran CPS ditinjau dari aspek sintaks, sistem sosial, peran guru, sistem 
pendukung, dampak instruksional yang diharapkan, dan dampak pengiring yang diduga akan muncul.

Tabel 1. Tahap perencanaan implementasi CPS di SMK Perbankan Syariah

\begin{tabular}{|c|c|c|c|c|c|c|}
\hline Sintaks & $\begin{array}{c}\text { Pertemuan } \\
\text { Ke- }\end{array}$ & $\begin{array}{l}\text { Sistem } \\
\text { Sosial }\end{array}$ & $\begin{array}{l}\text { Peran } \\
\text { Guru }\end{array}$ & $\begin{array}{l}\text { Sistem } \\
\text { pendukung }\end{array}$ & $\begin{array}{c}\text { dampak } \\
\text { instruksional }\end{array}$ & $\begin{array}{l}\text { Dampak } \\
\text { pengiring }\end{array}$ \\
\hline \multirow{6}{*}{$\begin{array}{l}\text { 1. Klarifikasi } \\
\text { Masalah } \\
\text { 2. Pengungkapan } \\
\text { pendapat } \\
\text { 3. Evaluasi dan } \\
\text { Pemilihan } \\
\text { 4. Implementasi }\end{array}$} & 1 & $\begin{array}{l}\text { Siswa duduk } \\
2 \text { orang } \\
\text { dalam } 1 \\
\text { bangku }\end{array}$ & $\begin{array}{l}\text { Fasilitator } \\
\text { dan } \\
\text { scaffolding }\end{array}$ & $\begin{array}{l}\text { LKS } \\
\text { bilangan } \\
\text { rasional. } \\
\text { Tugas } \\
\text { Individu }\end{array}$ & $\begin{array}{l}\text { Tercapai } \\
\text { kompetensi } \\
\text { tentang } \\
\text { bilangan } \\
\text { rasional }\end{array}$ & \multirow{6}{*}{$\begin{array}{l}\text { Berpikir } \\
\text { mandiri, } \\
\text { percaya diri. } \\
\text { Berpikir } \\
\text { mandiri, } \\
\text { mampu } \\
\text { menyampaikan } \\
\text { gagasan, } \\
\text { percaya diri. } \\
\text { Berpikir secara } \\
\text { kolaboratif, } \\
\text { mampu } \\
\text { menyampaikan } \\
\text { gagasan, } \\
\text { percaya diri, } \\
\text { bekerjasama } \\
\text { Berpikir secara } \\
\text { kolaboratif, } \\
\text { mampu } \\
\text { menyampaikan } \\
\text { gagasan, } \\
\text { percaya diri, } \\
\text { bekerjasama } \\
\text { Berpikir secara } \\
\text { kolaboratif, } \\
\text { mampu } \\
\text { menyampaikan } \\
\text { gagasan, } \\
\text { percaya diri, } \\
\text { bekerjasama } \\
\text { Berpikir secara } \\
\text { kolaboratif, } \\
\text { mampu } \\
\text { menyampaikan } \\
\text { gagasan, } \\
\text { percaya diri, } \\
\text { bekerjasama }\end{array}$} \\
\hline & 2 & $\begin{array}{l}\text { Siswa duduk } \\
2 \text { orang } \\
\text { dalam } 1 \\
\text { bangku }\end{array}$ & $\begin{array}{l}\text { Fasilitator } \\
\text { dan } \\
\text { scaffolding }\end{array}$ & $\begin{array}{l}\text { LKS } \\
\text { bentuk } \\
\text { akar } \\
\text { Tugas } \\
\text { Individu }\end{array}$ & $\begin{array}{l}\text { Tercapai } \\
\text { kompetensi } \\
\text { tentang } \\
\text { bentuk akar }\end{array}$ & \\
\hline & 3 & $\begin{array}{l}4-5 \text { siswa } \\
\text { duduk } \\
\text { berkelompok } \\
\text { berasal dari } \\
\text { tempat } \\
\text { duduk yang } \\
\text { berdekatan }\end{array}$ & $\begin{array}{l}\text { Fasilitator } \\
\text { dan } \\
\text { scaffolding }\end{array}$ & $\begin{array}{l}\text { LKS } \\
\text { bentuk } \\
\text { pangkat } \\
\text { Tugas } \\
\text { kelompok }\end{array}$ & $\begin{array}{l}\text { Tercapai } \\
\text { kompetensi } \\
\text { tentang } \\
\text { bentuk } \\
\text { pangkat }\end{array}$ & \\
\hline & 4 & $\begin{array}{l}4-5 \text { siswa } \\
\text { duduk } \\
\text { berkelompok } \\
\text { berasal dari } \\
\text { tempat } \\
\text { duduk yang } \\
\text { berdekatan }\end{array}$ & $\begin{array}{l}\text { Fasilitator } \\
\text { dan } \\
\text { scaffolding }\end{array}$ & $\begin{array}{l}\text { LKS } \\
\text { Logaritma } \\
\text { tugas } \\
\text { kelompok }\end{array}$ & $\begin{array}{l}\text { Tercapai } \\
\text { kompetensi } \\
\text { tentang } \\
\text { logaritma }\end{array}$ & \\
\hline & 5 & $\begin{array}{l}4-5 \text { orang } \\
\text { duduk } \\
\text { berkelompok } \\
\text { heterogen }\end{array}$ & $\begin{array}{l}\text { Fasilitator } \\
\text { dan } \\
\text { scaffolding }\end{array}$ & $\begin{array}{l}\text { Hubungan } \\
\text { bentuk } \\
\text { akar, } \\
\text { pangkat, } \\
\text { dan } \\
\text { logaritma } \\
\text { Tugas } \\
\text { kelompok }\end{array}$ & $\begin{array}{l}\text { Tercapai } \\
\text { kompetensi } \\
\text { tentang } \\
\text { hubungan } \\
\text { akar, } \\
\text { pangkat, } \\
\text { dan } \\
\text { logaritma }\end{array}$ & \\
\hline & 6 & $\begin{array}{l}4-5 \text { orang } \\
\text { duduk } \\
\text { berkelompok } \\
\text { heterogen }\end{array}$ & $\begin{array}{l}\text { Fasilitator } \\
\text { dan } \\
\text { scaffolding }\end{array}$ & $\begin{array}{l}\text { Aplikasi } \\
\text { akar, } \\
\text { pangkat, } \\
\text { dan } \\
\text { logaritma } \\
\text { Tugas } \\
\text { kelompok } \\
\text { dan } \\
\text { project. }\end{array}$ & $\begin{array}{l}\text { Tercapai } \\
\text { kompetensi } \\
\text { tentang } \\
\text { aplikasi dari } \\
\text { bentuk } \\
\text { pangkat, } \\
\text { akar, dan } \\
\text { logaritma. }\end{array}$ & \\
\hline
\end{tabular}


Lembar kerja siswa (LKS) disusun sedemikian rupa sehingga memudahkan siswa untuk memahami materi. LKS memiliki banyak manfaat seperti memandu dan memberi arah atau petunjuk dalam mengonstruksi pengetahuan yang baru (Fatimah, et al, 2017). Bahan ajar dalam LKS disajikan secara khas yang merupakan hasil pengintegrasian antara standar kompetensi mata pelajaran matematika dan kebutuhan matematika pada SMK Perbankan syariah. Materi pembelajaran dirancang supaya siswa terlebih dahulu memiliki pemahaman tentang konsep operasi bilangan real yang baik hingga akhirnya dapat menerapkannya pada masalah perbankan. LKS yang diberikan diharapkan mampu memberi dampak instruksional secara langsung juga memberi dampak pengiring yang positif seperti yang sudah direncanakan.

Rencana pada Tabel 1 kemudian diimplementasikan di kelas. Hasil dari implementasi dirangkum dan diinterpretasikan berdasarkan hasil observasi dan dokumentasi. Rangkuman hasil interpretasi disajikan dalam Tabel 2. Rangkuman merupakan bagian inti dari pembelajaran. Bagian pendahuluan dan penutup tidak digambarkan dalam penelitian ini.

Tabel 2. Hasil observasi dari interaksi sosial berdasarkan sintaks Model CPS

\begin{tabular}{|c|c|c|}
\hline Pertemuan & Sintaks & Uraian \\
\hline \multirow[t]{5}{*}{1} & Klarifikasi Masalah & $\begin{array}{l}\text { Siswa masih beradaptasi dengan LKS yang disajikan. } \\
\text { Setelah siswa membaca LKS, mereka cenderung menunggu } \\
\text { arahan guru untuk mengisi LKS. }\end{array}$ \\
\hline & Pengungkapan & Siswa kurang berani memberikan pendapat. \\
\hline & Pendapat. & $\begin{array}{l}\text { Hampir semua siswa kurang percaya diri menuliskan } \\
\text { jawabannya di LKS. } \\
\text { Guru dan observer menggali pengetahuan dan pengalaman } \\
\text { beberapa siswa yang terlihat menuliskan jawaban. }\end{array}$ \\
\hline & Evaluasi dan Pemilihan & $\begin{array}{l}\text { Siswa kurang terlihat berdiskusi dengan temannya untuk } \\
\text { menentukan solusi. }\end{array}$ \\
\hline & Implementasi & $\begin{array}{l}\text { Siswa cenderung menunggu komando guru untuk } \\
\text { mengimplementasikan strategi yang telah ditetapkan pada } \\
\text { tahap sebelumnya. }\end{array}$ \\
\hline \multirow[t]{7}{*}{2} & Klarifikasi Masalah & $\begin{array}{l}\text { Beberapa siswa sudah mulai mandiri mengidentifikasi } \\
\text { masalah yang disajikan pada LKS. } \\
\text { Guru memberi klarifikasi masalah jika dibutuhkan oleh siswa. }\end{array}$ \\
\hline & $\begin{array}{l}\text { Pengungkapan } \\
\text { Pendapat. }\end{array}$ & $\begin{array}{l}\text { Lima orang siswa sudah mulai berani mengemukakan } \\
\text { pendapatnya. }\end{array}$ \\
\hline & & $\begin{array}{l}\text { Guru dan observer menggali pengetahuan dan pengalam lima } \\
\text { siswa tersebut. }\end{array}$ \\
\hline & Evaluasi dan Pemilihan & $\begin{array}{l}\text { Siswa sudah mulai berdiskusi untuk menentukan strategi } \\
\text { pemecahan masalah. }\end{array}$ \\
\hline & & $\begin{array}{l}\text { Banyak siswa yang memerlukan bantuan guru, sehingga tidak } \\
\text { semua siswa terlayani. }\end{array}$ \\
\hline & & $\begin{array}{l}\text { Guru memberikan intervensi terhadap siswa tentang strategi } \\
\text { pemecahan masalah. }\end{array}$ \\
\hline & Implementasi & $\begin{array}{l}\text { Siswa menyelesaikan masalah setelah bersama-sama } \\
\text { menyepakati strategi. }\end{array}$ \\
\hline \multirow[t]{2}{*}{3} & Klarifikasi Masalah & $\begin{array}{l}\text { Siswa berdiskusi mengidentifikasi masalah. } \\
\text { Guru memberikan klarifikasi masalah terhadap setiap } \\
\text { kelompok. }\end{array}$ \\
\hline & $\begin{array}{l}\text { Pengungkapan } \\
\text { Pendapat. }\end{array}$ & $\begin{array}{l}\text { Siswa berdiskusi untuk mengungkapkan pendapat mengenai } \\
\text { strategi-strategi pemecahan masalah berdasarkan } \\
\text { pengalaman belajar ketika di SMP. }\end{array}$ \\
\hline
\end{tabular}




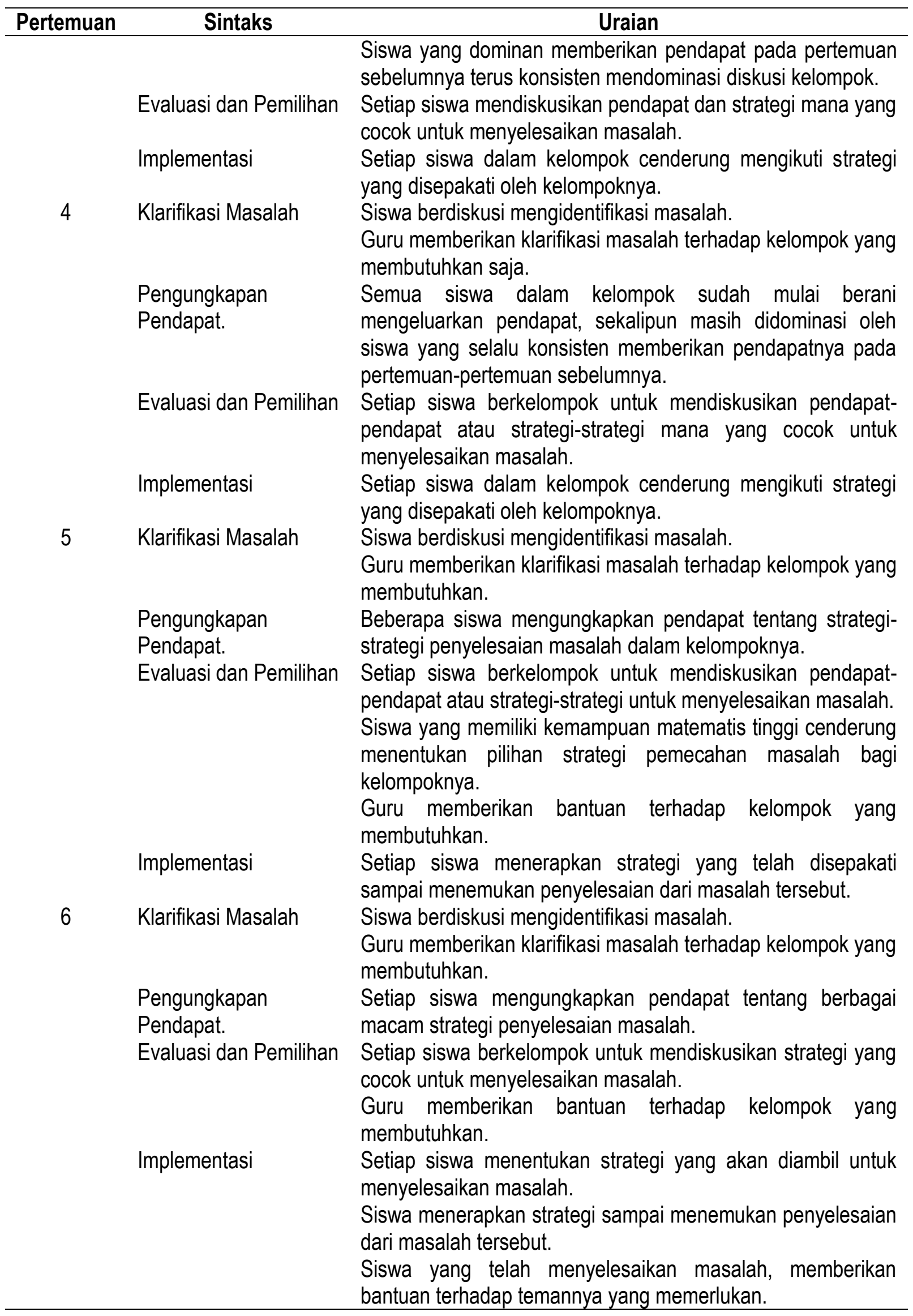


Tabel 2 menunjukkan bahwa rencana yang disusun dapat diimplementasikan sesuai dengan rencana. Sintaks model pembelajaran CPS dapat berjalan sesuai dengan tahapannya, meskipun di awal-awal pertemuan siswa cenderung kurang berani mengemukakan pendapat. Setiap siswa secara bertahap mengalami perubahan pola berpikir. Awalnya mereka tertutup, kemudian mulai terbuka untuk memberikan gagasan, meskipun setiap siswa memiliki perbedaan (selang waktu) untuk terbuka pemikirannya. Pelan tapi pasti setiap individu terdorong untuk menggunakan kognisinya secara maksimal berpikir secara kreatif untuk mengeluarkan, mengembangkan, dan menerapkan ide-idenya. Krulik \& Rudnick (1995) menyatakan bahwa pada tingkat berpikir kreatif, seseorang dapat mensintesis ide-ide, membangkitkan ide-ide, dan menerapkan ide-ide tersebut.

Sistem sosial selama proses pembelajaran berjalan dengan baik. Hal tersebut sesuai dengan rencana awal yang merupakan upaya untuk mengelola dinamika kelas awal bagi siswa yang belum terlalu saling mengenal. Guru pun belum mengetahui kemampuan awal matematis siswa (setiap individu) secara mendalam. Pengelolaan dinamika sosial kelas oleh guru diperlukan terkait dengan penyesuaian sosial dan akademik siswa untuk mengembangkan respons sosial terhadap teman sebaya secara langsung (Braun, 2019). Hasil observasi menunjukkan bahwa pengelompokkan mulai dari kelompok kecil (teman sebangku), kemudian kelompok yang lebih besar (teman antar bangku), hingga kelompok yang heterogen berdampak pada aspek instruksional dan aspek pengiring. Aspek instruksional mengakibatkan siswa memiliki gagasan dan berani mengeluarkan gagasannya sehingga implementasi pemecahan masalah mudah untuk dilakukan. Aspek pengiring terlihat sangat jelas siswa yang awalnya kurang berani mengemukakan gagasan lambat laun tumbuh rasa percaya dirinya dan setiap anggota kelompok bekerja secara kolaboratif.

Guru memberikan peran penting pada awal-awal pertemuan, kemudian berangsur menjadi fasilitator seperti yang telah direncanakan. Guru juga melakukan scaffolding secara efektif mulai dari pertemuan keempat. Scaffolding merupakan upaya pemecahan masalah secara bersama-sama antara guru dan siswa supaya siswa dapat sesegera mungkin untuk dapat menyelesaikan tugasnya secara mandiri (Bikmaz, 2010). Scaffolding terhadap individu tertentu dilakukan pada pertemuan awal, selanjutnya secara efektif scaffolding dilakukan oleh guru dalam kelompok. Hal tersebut dilakukan karena dalam suatu kelompok terdapat siswa yang memiliki kemampuan matematis lebih tinggi sehingga scaffolding dapat juga dapat dilakukan antara siswa.

Sistem pendukung utama dalam implementasi model pembelajaran CPS adalah LKS. Penggunaan LKS sangat menunjang keberlangsungan interaksi antara matematika, guru, dan siswa. LKS berperan sebagai alat mediasi ketiga aspek tersebut. LKS memfasilitasi kompetensi dasar yaitu menerapkan konsep bilangan berpangkat, bentuk akar dan logaritma dalam menyelesaikan masalah. Selain itu, penerapan juga dilakukan terhadap masalah perbankan yang penyelesaiannya menggunakan konsep bentuk pangkat, akar, dan logaritma. Secara khusus, LKS untuk kelas awal dirancang untuk mengidentifikasi kemampuan awal matematis. Hal tersebut penting dilakukan pada siswa kelas awal (Wu, et al, 2015).

\section{KESIMPULAN}

Model pembelajaran CPS dapat diimplementasikan pada siswa kelas awal (siswa baru) SMK Keahlian Perbankan Syariah. Sebelum model pembelajaran CPS diimplementasikan diperlukan identifikasi tentang masalah siswa di kelas awal dan integrasi masalah matematis pada konteks perbankan syariah. Identifikasi sangat berguna untuk menentukan sistem sosial siswa di kelas, peran guru, sistem pendukung, dampak instruksional dan pendukung sehingga sintaks model pembelajaran CPS dapat diimplementasikan. Aspek penting dari implementasi model pembelajaran CPS adalah bagaimana membelajarkan siswa untuk mengeluarkan seluruh gagasannya yang kreatif dalam memecahkan masalah matematis sehingga diperoleh solusi yang masuk akal. 


\section{REKOMENDASI}

Implementasi model pembelajaran CPS pada penelitian ini hanya dilakukan dalam satu kelas. Penelitian selanjutnya dapat membandingkannya dengan kelas kontrol untuk mengetahui efek atau peningkatan suatu kemampuan matematis akibat dari implementasi model tersebut. Selain itu, implementasi model pembelajaran CPS pada penelitian ini hanya mengambil satu kasus yaitu pada SMK Keahlian Perbankan Syariah. Oleh karena itu, peneliti berikutnya dapat mengimplementasikan dan memberi gambaran pada bidang/program/kompetensi keahlian lainnya.

\section{UCAPAN TERIMAKASIH}

Ucapan terima kasih kami sampaikan kepada: (1) Kemenristekdikti yang telah mendanai penelitian ini; (2) Guru dan Siswa yang terlibat dan berpartisipasi dalam penelitian ini; dan (3) Bapak Kepala Sekolah yang telah memberikan izin untuk melakukan penelitian.

\section{DAFTAR PUSTAKA}

Apiati, V., \& Fatimah, A. (2017). Peningkatan kemampuan komunikasi matematik siswa yang menggunakan model creative problem solving (CPS). JP3M Jurnal Penelitian Pendidikan dan Pengajaran Matematika. Vol. 3 No. 1:71-76.

Bikmaz, F. H., Çeleb, Ö., Aslıhan, A. T. A., Eren, Ö. Z. E. R., Soyak, Ö., \& Reçber, H. (2010). Scaffolding strategies applied by student teachers to teach mathematics. The International Journal of Research in Teacher Education, Vol.1 No. 3: 25-36.

Braun, S.S., Zadzora, K.M., Miller, A.M. et al. (2019). Predicting elementary teachers' efforts to manage social dynamics from classroom composition, teacher characteristics, and the early year peer ecology. Soc Psychol Educ. 1-23. https://doi.org/10.1007/s11218-019-09503-8.

Effendi, A. (2016a). Implementasi Creative Problem Solving untuk Meningkatkan Self-Regulated Learning Siswa SMA. Seminar Nasional Matematika Dan Pendidikan Matematika UNY. 916.

Effendi, A. (2016b). Implementasi Model Creative Problem Solving Untuk Meningkatkan Kemampuan Metakognitif Berdasarkan Kemampuan Awal Matematis Siswa. JPPM. Vol. 9 No. 2: 165-176.

Effendi, A. (2017). Implementation of Creative Problem Solving Model to Improve The High School Student's Metacognitive. Journal of Physics: Conference Series. Ser. 812 012065. 1-6.

Fatimah, A. T., Amam, A., \& Effendi, A. (2017). Konstruksi Pengetahuan Trigonometri Kelas X Melalui Geogebra dan LKPD. JNPM (Jurnal Nasional Pendidikan Matematika). Vol. 1 No. 2: 178-188.

Fatimah, A. T., Effendi, A., \& Amam, A. (2018). Koneksi Matematis pada Konsep Ekonomi (Permintaan dan Penawaran). Teorema, 2(2),107-116.

Fatimah, A. T. \& Amam, A. (2018). Rencana Pelaksanaan Pembelajaran Matematika di Sekolah Menengah Kejuruan. JPPM, 11(2), 77-90. 
Fatimah, A. T. \& Zakiah, N. E. (2018). Kelancaran Prosedural Matematis Dalam Pemecahan Masalah Konteks Pemasaran. Mathline Jurnal Matematika dan Pendidikan Matematika, 3(2), 141-150.

Fatimah, A. T., Pramuditya, S. A. \& Wahyudin (2019). Imitative and creative reasoning for mathematical problem solving (in context horticultural agribusiness). Journal of Physics: Conf. Series 1157 042092: 1-6.

Fatimah, A.T. \& Zakiah, N. E. (2019). Matematika Pada Kompetensi Teknik Dan Bisnis Sepeda Motor. Jumlahku: Jurnal Matematika IImiah STKIP Muhammadiyah Kuningan, 5(1), 31-47.

Hancock, D. R. \& Algozzine, B. (2006). Doing Case Study Research. Newyork dan London: Theachers Collage Press.

Joyce, B., Weil, M., \& Calhoun, E. (2009). Model of teaching-Model-model (8th ed.) Pembelajaran. Yogyakarta: Pustaka Pelajar.

Krulik Stephen \& Rudnick Jesse A 1995 The New Sourcebook for Teaching Reasoning and Problem Solving in Elementary School (Boston : Temple University).

Pepkin, K. L. (2004) Creative Problem Solving In Math. Tersedia di: http://www.uh.edu/hti/ cu/2004/v02/04.htmfl [4 Februari 2007].

Permendikbud Nomor 34 Tahun 2018 tentang Standar Nasional Pendidikan SMK/MAK.

Turmuzi, M. Sripatmi, S. Azmi, S. \& Hikmah, N. (2018). Penerapan Model Pembelajaran Creative Problem Solving (CPS) Untuk Meningkatkan Kemampuan Pemecahan Masalah Mahasiswa Pendidikan Matematika. Jurnal Pijar MIPA. Vol. 13 No. 1: 45-50.

Undang-Undang Nomor 20 Tahun 2003 tentang Sistem Pendidikan Nasional.

Wu, Q., Lei, P., DiPerna, J.C. et al. (2015). Identifying Differences in Early Mathematical Skills Among Children in Head Start. Int J of Sci and Math Educ. Vol 13 No. 6: 1403-1423. 